\title{
Effects of storage and extraction procedures on yields of lipophilic metabolites from the brown seaweeds Dictyota ciliolata and D. menstrualis
}

\author{
Greg Cronin ${ }^{1, *}$, Niels Lindquist ${ }^{1}$, Mark E. Hay ${ }^{1}$, William Fenical ${ }^{2}$ \\ ${ }^{1}$ University of North Carolina at Chapel Hill, Institute of Marine Sciences, Morehead City, North Carolina 28557, USA \\ ${ }^{2}$ Scripps Institution of Oceanography, University of California-San Diego, La Jolla, California 92093-0236, USA
}

\begin{abstract}
Investigations focused on the ecological roles of marine secondary metabolites have become common, but marine ecologists have rarely assessed how methodologies used in sample preparation affect the extractability and stability of secondary metabolites and, thus, measurements of intraspecific and interspecific compound variance. We assessed various procedures for storing, drying, and extracting samples of 2 chemically defended brown seaweeds Dictyota ciliolata and D. menstrualis. These plants contain the diterpenoid alcohols pachydictyol $\mathrm{A}$, dictyol $\mathrm{B}$ acelate, and dictyol $\mathrm{E}$ that are relatively stable under all test conditions. In contrast, the related diterpenoid dialdehyde, dictyodial, decomposed when plant tissues or crude extracts were stored at $-25^{\circ} \mathrm{C}$ for 13 to 27 wk or when tissues or extracts were freeze-dried or subjected to high vacuum $(<0.01$ torr $)$, methods that are commonly used in studies of marine chemical ecology. The stability of dictyodial was species-specific, degrading more in $D$. ciliolata than in $D$. menstrualis. During a few extractions, dictyodial reacted with methanol $(\mathrm{MeOH})$ to yield an artifact resulting from the addition of 2 molecules of $\mathrm{MeOH}$ per molecule of dictyodial. A mixture of 2:1 dichloromethane (DCM) and $\mathrm{MeOH}$ tended to extract the lipophilic secondary metabolites better than $\mathrm{MeOH}$ or DCM alone. Metabolites were also afforded some protection against degradation when fresh tissue was submerged in 2:1 DCM:MeOH diring storage at $-25^{\circ} \mathrm{C}$. Results of this investigation indicate that storage, extraction, and quantification methods need to be optimized for analyses of individual compounds and that even identical compounds can behave differently when they occur in different species.
\end{abstract}

KEY WORDS: Chemical ecology $\cdot$ Dictyols $\cdot$ Dictyota $\cdot$ Extraction $\cdot$ HPLC $\cdot$ Methods $\cdot$ Secondary metabolites - Terpenes

\section{INTRODUCTION}

During the last decade, our understanding of how marine plants and animals use secondary metabolites as defenses against consumers and competitors has expanded tremendously (reviewed by Hay \& Steinberg 1992, Paul 1992, Pawlik 1993). Previous studies documented the ecological roles played by these compounds but relatively few have investigated, in a rigorous manner, how compounds varied qualitatively and quantitatively among plant portions, individuals, locations, seasons, etc. (for exceptions see Ragan \&

\footnotetext{
- Present address: Dept of Biological Sciences, Univ. of Notre Dame, Notre Dame, Indiana 46556، USA
}

Jensen 1978, Phillips \& Towers 1982, Steinberg 1984, 1989, Johnson \& Mann 1986, Paul \& Fenical 1987, Hay et al. 1988a, Paul \& Van Alstyne 1988, 1992. Van Alstyne 1988, 1989, Carlson et al. 1989, Ilvessalo \& Tuomi 1989, Tugwell \& Branch 1989, Pfister 1992. Yates \& Peckol 1993). Advancement of our understanding of the ecological and evolutionary aspects of marine secondary metabolites will depend greatly on assessments of this variance, yet there are few studies evaluating which general methodological procedures should be employed (Norris \& Fenical 1985).

The bioactive nature of many secondary metabolites suggests that some could be labile, necessitating the use of methodologies that do not alter the concentration or structure of compounds. Previous work has shown that the yields of secondary metabolites can be changed by 
biochemical activity (de Scisciolo et al. 1990, Goodrich et al. 1990, Kleiner 1991), heat (Cork \& Krockenberger 1991, Newman et al. 1992), light (Cork \& Krockenberger 1991), vacuum (Hay et al. 1988b), extraction solvent (Hagerman 1988, Carlson et al. 1989, Muzika et al. 1990, Cork \& Krockenberger 1991), drying procedure (Lindroth \& Pajutee 1987, Hagerman 1988, Cork \& Krockenberger 1991), and duration of extraction (Lindroth \& Pajutee 1987, Zobel \& Brown 1988). Enzymatic conversion of secondary metabolites can rapidly alter less active precursors to more potent deterrents (reviewed by Duffey \& Felton 1989), having important ecological implications as in the case of activation of chemical defenses (Newman et al. 1992, Paul \& Van Alstyne 1992).

Because so many factors can affect the measurement of ecologically important secondary metabolites, we tested how several commonly used storage and extraction procedures affected the yields of lipophilic secondary metabolites from 2 chemically defended brown seaweeds in the order Dictyotales, Dictyota menstrualis (previously D. dichotoma) and D. ciliolata. D. menstrualis produces 2 structurally similar diterpenoid alcohols, pachydictyol A and dictyol E (Hay et al. 1987), and the diterpenoid dialdehyde, dictyodial. D. ciliolata also produces pachydictyol $\mathrm{A}$ and dictyodial, as well as dictyol $B$ acetate (Fig. 1). These terpenes are representative, in terms of size and polarity, of many secondary metabolites produced by marine algae (Faulkner 1993 and papers cited therein), so our findings may apply more broadly.

In this study, we address the following questions: (1) Is there a general extraction procedure that optimizes yields of all of our lipophilic compounds, or do optimal procedures for these related secondary metabolites differ? (2) How does duration and method of storage prior to analysis affect compound yield? (3) Do some procedures cause secondary metabolites from Dictyota ciliolata and $D$. menstrualis to degrade or to form artifactual derivatives?

\section{MATERIALS AND METHODS}

Isolation of secondary metabolites. To identify the secondary metabolites in the Dictyota spp. at our study site and to acquire pure compounds for standards, we made a mixed collection of $D$. cillolata and D. menstrualis from a rock jetty located at Radio Island, near Beaufort, North Carolina, USA, in summer 1990. The collection was frozen, lyophilized, and then extracted in a $2: 1$ mixture of dichloromethane (DCM) and methanol (MeOH). Individual metabolites were purified using vacuum-flash chromatography over silica gel followed by high-performance liquid chromatography (HPLC). The identification of pachydictyol A, dictyol $\mathrm{E}$, dictyol $\mathrm{B}$ acetate, and dictyodial was achieved by comparison of nuclear magnetic resonance (NMR) spectroscopy with known standards. The structure of the methoxy-bisacetal of dictyodial was elucidated by ${ }^{1} \mathrm{H}$ and ${ }^{13} \mathrm{C}$ NMR in conjunction with infrared and mass-spectral studies.

Extraction procedures. To test how extraction procedures affected yield of secondary metabolites, individual Dictyota ciliolata and $D$. menstrualis plants were collected on August 24, 1990, cut into small pieces $\left(<1 \mathrm{~cm}^{2}\right)$, and stirred in seawater to assure homogeneity. After straining and blotting to remove excess seawater, a $1 \mathrm{~g}$ portion of tissue (range 0.943 to $1.186 \mathrm{~g}$ ) from each plant was assigned to each of 8 extraction procedures (summarized in Fig. 2A). Three different methods of water removal at non-elevated temperatures were tested: (1) DCM-water partition after the extraction solvents were evaporated under a stream of nitrogen gas (extraction methods 1 to 3); (2) use of a speedvac (Savant Instruments, Inc.) to remove water, $\mathrm{MeOH}$, and ethanol $(\mathrm{EtOH})$ used during extractions (extraction methods 4 and 5); and (3) lyophilization of frozen tissue (extraction methods 6 to 8). The extraction solvents tested were $\mathrm{MeOH}, \mathrm{EtOH}$, DCM, and a 2:1 mixture of DCM:MeOH. DCM alone

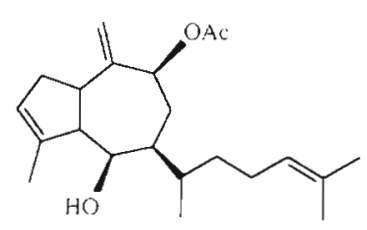

Dictyol 8 acetate

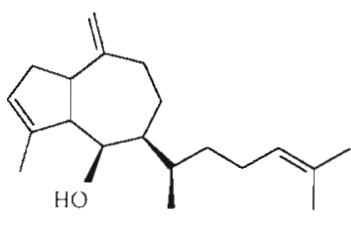

Pachydictyol A

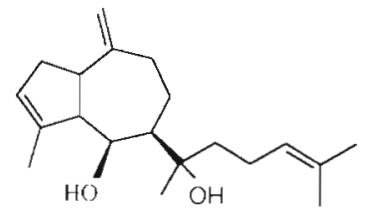

Dictyol E

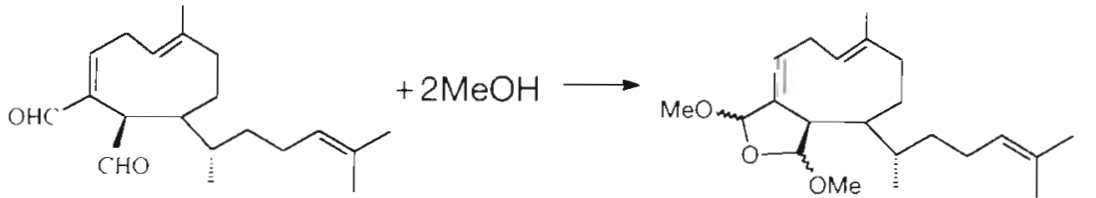

Dictyodial
Fig. 1. Structures of compounds analyzed in this study. The methoxy-bisacetal is an artifact produced when dictyodial reacts with methanol 
was not used to extract wet samples because it is immiscible with water. The 2:1 mixture of DCM: $\mathrm{MeOH}$ was not used in the speedvac methods because DCM would damage the vacuum pump. Plant samples were placed in $6 \mathrm{ml}$ of solvent, ground for $60 \mathrm{~s}$ with a Brinkmann homogenizer (model PCU-11, setting 6), centrifuged, and the supernatant saved. The pellet was suspended in another $6 \mathrm{ml}$ of solvent, ground for an additional $30 \mathrm{~s}$, centrifuged, and the supernatant combined with the previous one.

Organic solvents were evaporated from extraction methods 1 to 3 and 6 to 8 using a stream of nitrogen gas. Lipophilic compounds in these extracts were separated from the water with 2 DCM-water partitions, first with $3 \mathrm{ml}$ of DCM then with $1 \mathrm{ml}$ of DCM (extraction methods 1 to 3 ). The combined DCM washings were evaporated under nitrogen. In extraction methods 4 and 5 , extracts were dried in a speedvac at $<0.01$ torr.

Concentrations of compounds from replicate portions of an individual plant (i.e. a block) treated by different extraction procedures were determined by analytical HPLC on the same day to assure that differences between extraction methods would not be due to temporal drift in instruments or storage artifacts. To express compound concentrations on a dry mass basis, the percent dry mass of each plant was calculated using the mean dry mass: wet mass ratio of portions that were freeze-dried for extraction methods 6 to 8. Differences in extraction efficiency among extraction methods were analyzed by 2 -factor ANOVA (replicates among the extraction methods were blocked by individual plant) followed by Tukey's Studentized range test (SAS 1991).

Sample storage. To determine if Dictyota spp. secondary metabolites degraded as a function of method and duration of storage, $D$. ciliolata and $D$. menstrualis collected from the rock jetty at Radio Island on July 20 , 1991, were subjected to 4 storage methodologies. For each species, individual plants were cut into small pieces, stirred in seawater, drained, and from each plant we took two 0.994 to $1.006 \mathrm{~g}$ (wet mass) samples and one 1.997 to $2.007 \mathrm{~g}$ sample. One of the smaller samples was frozen for 13 to $27 \mathrm{wk}$ prior to extraction in 2:1 DCM: $\mathrm{MeOH}$. The other was stored at $-25^{\circ} \mathrm{C}$ in $6 \mathrm{ml}$ of $2: 1 \mathrm{DCM}: \mathrm{MeOH}$. The larger sample was immediately extracted in 2:1 DCM:MeOH. The extract was split into 3 equal portions that were either (1) analyzed within $2 \mathrm{wk}$, (2) stored in DCM under air for 3 to $6 \mathrm{mo}$, or (3) stored in DCM under nitrogen gas for 3 to 6 mo.

Of the 15 Dictyota menstrualis plants, 6 were analyzed with $\mathrm{HPLC}$ after 13 wk of storage at $-25^{\circ} \mathrm{C}$. Because our HPLC malfunctioned, the remaining $9 \mathrm{D}$. menstrualis and $15 \mathrm{D}$. ciliolata samples were analyzed after 25 to $27 \mathrm{wk}$ of storage at $-25^{\circ} \mathrm{C}$. All replicates among treatments from an individual plant (i.e. a block) were analyzed on the same day (except the one analyzed within $2 \mathrm{wk}$ ) to prevent systematic errors from influencing between-treatment differences. Data from $D$. menstrualis samples stored for $13 \mathrm{wk}$ were analyzed separately from the samples stored for 25 to 27 wk because significant differences between the 2 periods were detected for some compounds. Significant differences in metabolite concentration among storage treatments were determined by a 2 -factor ANOVA (blocked by plant) followed by Tukey's Studentized range test (SAS 1991).

HPLC analysis. Prior to injecting samples into the HPLC system, each extract was placed under high vacuum $(<0.01$ torr) for $5 \mathrm{~min}$ to remove residual solvents, dissolved in $2 \mathrm{ml}$ of hexanes, and then added to a small column containing $500 \mathrm{mg}$ of Florisil. The vial containing the extract was rinsed with $1 \mathrm{ml}$ of hexanes and this was also added to the Florisil column. Another $3 \mathrm{ml}$ of hexanes was then suctioned through the Florisil column. This eluted triglycerides and other very nonpolar compounds. A second fraction, eluted with $6 \mathrm{ml}$ of a 65:35 mixture of hexanes and anhydrous diethyl ether, contained dictyols, sterols, and small quantities of other compounds. The third fraction, eluted with 100\% diethyl ether, did not contain dictyols. The second fraction was dried with nitrogen gas and placed under high vacuum for $5 \mathrm{~min}$ to remove residual solvent.

To quantify compounds in this fraction, we used an analytical HPLC system consisting of a Beckman $110 \mathrm{~B}$ solvent delivery module, a $20 \mu \mathrm{l}$ sample loop, a $4.6 \times$ $100 \mathrm{~mm}$ silica column with $3 \mu \mathrm{m}$ particle size and $100 \AA$ pore size (Rainin Instrument Co., Inc., Microsorb ShortOne), a Spectra Physics RI detector (model SP8430), and a Spectra Physics printing integrator (model SP4290). Calibration curves for the HPLC analyses had previously been constructed from 3 to 6 replicate injections of 2 to $100 \mu \mathrm{g}$ each of pachydictyol A, dictyol B acetate, and dictyol $\mathrm{E}$. The instability of dictyodial prevented construction of a calibration curve.

Extraction efficiency. As a crude determination of the efficiency of our extraction and quantification procedures, an alga with a known concentration of secondary metabolites was created by adding $0.2 \mathrm{mg}$ each of pachydictyol $\mathrm{A}$, dictyol $\mathrm{B}$ acetate, and dictyol $\mathrm{E}$ to $100 \mathrm{mg}$ of ground, lyophilized Ulva sp., a green alga which does not contain dictyols. The alga and compounds were submerged in diethyl ether, mixed, and the ether evaporated under a gentle stream of nitrogen. This alga was then double-extracted in $2: 1$ DCM: $\mathrm{MeOH}$ (extraction method 7).

To determine if any compounds were lost while preparing samples for HPLC analysis, $0.2 \mathrm{mg}$ of pachy- 
dictyol $A$, dictyol $B$ acetate, and dictyol $E$ were simultaneously added to Florisil solid-phase columns and processed as if they were a crude lipophilic extract. A mixture containing $0.2 \mathrm{mg}$ of each metabolite was injected directly into the HPLC as a reference. These data were analyzed with a 1-way ANOVA followed by Tukey's Studentized range test (SAS 1991).

\section{RESULTS}

Four diterpenes, pachydictyol A, dictyol B acetate. dictyol $E$, and dictyodial, were recovered from the mixed collection of Dictyota ciliolata and D. menstrualis. In addition, the methoxy-bisacetal of dictyodial was isolated. This compound was an artifact produced when dictyodial reacts with methanol during extraction (Fig. 1).

The RI detector response for each compound showed a strong linear relation with concentration $\left(\mathrm{r}^{2}>0.991\right)$ although the slopes of the regression lines were significantly different ( $\mathrm{p}<0.001$, ANCOVA). The slopes of the regressions for pachydictyol $\mathrm{A}$, dictyol $\mathrm{B}$ acetate, and dictyol $E$ were $1.84,1.42$, and $1.35 \times 10^{4}$ peak area units $\mu \mathrm{g}^{-1}$ compound and their $y$-intercepts were -4.25 , -3.03 , and $-9.35 \times 10^{4}$ area units, respectively.

\section{Extraction methodology}

The amounts of lipophilic metabolites recovered from Dictyota ciliolata and D. menstrualis tissue varied depending on solvent and means of water removal (Fig. 2). For dictyol B acetate, yields were highest if lyophilized tissues were extracted with 2:1 DCM: $\mathrm{MeOH}$ or for any of our test solvents if extraction was followed by a DCM: water partition of the extract (Fig. 2B). When lyophilized tissues were extracted with 2:1 DCM: $\mathrm{MeOH}$, yields were significantly higher than when these same tissues were extracted with either $\mathrm{DCM}$ or $\mathrm{MeOH}$ alone or when frozen tissues were extracted with EtOH or MeOH followed by speedvac.

The yield of pachydictyol A differed between extraction methods in a pattern crudely similar to that for dictyol $B$ acetate (Fig. 2B, C). Although many particular contrasts were not significant, the $2: 1$ mixture of DCM and $\mathrm{MeOH}$ (extraction methods 7 and 1) tended to extract dictyols better than DCM (extraction method 8), MeOH (extraction methods 2, 5, and 6), or EtOH (extraction methods 3 and 4) alone (Fig. 2C). These trends were statistically significant $(\alpha=0.05)$ for extraction method 7 vs 4, 5, and 6, and for extraction method 1 vs extraction methods 4 and 5. Lyophilized tissue extracted in $2: 1 \mathrm{DCM}: \mathrm{MeOH}$ (extraction method 7) yielded $51 \%$ more pachydictyol A
A

\begin{tabular}{|c|c|c|}
\hline $\begin{array}{c}\text { Extraction } \\
\text { method }\end{array}$ & $\begin{array}{c}\text { Extraction } \\
\text { Solvent }\end{array}$ & $\begin{array}{c}\text { Water } \\
\text { removal } \\
\text { DCM:Water } \\
\text { partition of } \\
\text { extract }\end{array}$ \\
\hline 1 & $2: 1 \mathrm{DCM}: \mathrm{MeOH}$ \\
$\mathrm{MeOH}$ & $\mathrm{EtOH}$ & Speed $\mathrm{Vac}$ of \\
3 & $\mathrm{EtOH}$ & crude extract \\
\hline 4 & $\mathrm{MeOH}$ & Lyophilization \\
5 & $\mathrm{MeOH}$ \\
6 & $2: 1 \mathrm{DCM}: \mathrm{MeOH}$ & of \\
7 & $\mathrm{DCM}$ & whole tissue \\
\hline 8 & &
\end{tabular}

B
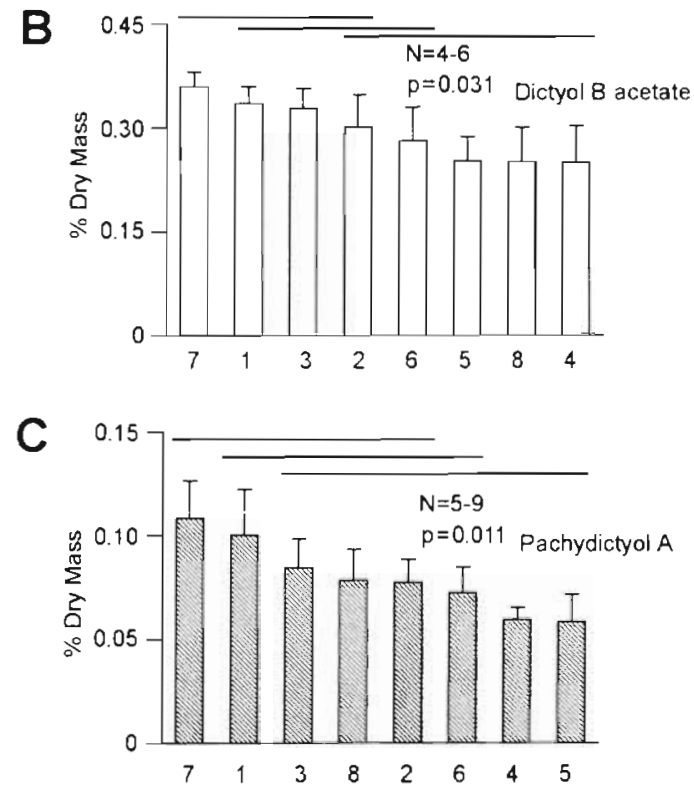

D

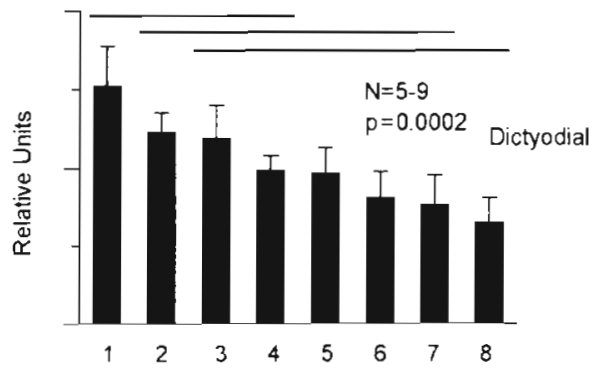

Fig. 2. (A) Summary of the treatments used to remove water and extract lipophilic compounds from samples of Dictyota ciliolata and $D$. mentrualis. Yield (mean $+1 \mathrm{SE}$ ) of $(\mathrm{B})$ dictyol $\mathrm{B}$ acetate, (C) pachydictyol $A$, and (D) dictyodial as a function of extraction methodology. The number below each bar represents the extraction method (number) from (A). p-values are from the 'extraction method' source of error from a 2-way ANOVA with extraction methods and individual plants as the 2 factors. Horizontal lines above the bars join means that do not differ significantly ( $\alpha \leq 0.05$, Tukey's Studentized range test)

than lyophilized tissue extracted in $\mathrm{MeOH}$ alone (extraction method 6).

Freeze-drying, as opposed to solvent, did not consistently affect yields of pachydictyol $A$ or dictyol $B$ acetate but did significantly reduced yields of dictyo- 
dial for thawed versus lyophilized tissue extracted with 2:1 DCM:MeOH (extraction method 1 vs 7, Fig. 2D). When $\mathrm{MeOH}$ was the extraction solvent, lyophilization appeared to decrease dictyodial yield by $34 \%$ (extraction method 2 vs 6), but this decrease was not statistically significant. Recovery of dictyodial tended, though not always significantly, to be lower in those extraction methods where extreme vacuum $(<0.01$ torr) was used to remove water (lyophilization and speedvac; extraction methods 4 to 8 ).

When comparing the yields of pachydictyol A, dictyol $B$ acetate, and dictyodial extracted with the $2: 1$ mixture of DCM:MeOH versus either DCM or $\mathrm{MeOH}$ alone, the $2: 1$ mixture gave the highest average yield in 5 of 6 possible comparisons (extraction method 1 vs 2 , and 7 vs 6 and 8 for each compound), suggesting that it may be most useful for general extractions of these types of metabolites. $\mathrm{MeOH}$ alone gave the highest average yield in 1 of 6 (extraction method 2 vs 1 and 6 vs 7 and 8 for each compound) comparisons and DCM in 0 of 3 (extraction method 8 vs 6 and 7 for each compound) comparisons (Fig. 2).

When the freeze-dried Ulva sp. containing $0.2 \%$ dry mass of pachydictyol $\mathrm{A}$, dictyol $\mathrm{B}$ acetate, and dictyol $\mathrm{E}$ was double-extracted in 2:1 DCM: $\mathrm{MeOH}, 88$ to $90 \%$ of each of the dictyols was recovered (Fig. 3). The Florisil column pretreatments did not decrease yields of the dictyols; the $5 \%$ increase in pachydictyol A concentration with this treatment possibly resulted from the evaporation of solvent when the samples were dissolved in HPLC solvent before injection. The standard error of the measurements for these 3 treatments ranged from 1.7 to $2.4 \%$ of the mean, indicating the precision of measurements was good.

\section{Sample storage}

Yields of dictyol B acetate did not differ significantly among treatments of Dictyota ciliolata that were stored in the freezer for 25 to $27 \mathrm{wk}$; however, yields from stored treatments were all unexpectedly higher than those from samples analyzed within $2 \mathrm{wk}$ of collection (Fig. 4A). Dictyol E concentrations did not differ among storage treatments when $D$. menstrualis samples were stored for 13 or 25 to $27 \mathrm{wk}$ (Fig. 4A); however, samples stored for 25 to $27 \mathrm{wk}$ had significantly less dictyol $E$ than samples analyzed within $2 \mathrm{wk}$ of collection. In $D$. ciliolata, the concentration of pachydictyol $A$ in tissue frozen in solvent was significantly higher than in the tissue frozen without solvent, but neither of these yields differed significantly from the remaining 3 treatments (Fig. 4B). Pachydictyol A concentration did not differ significantly among storage treatments in D. menstrualis samples (Fig. 4B). Yields of dictyodial
Standard injected directly Standard passed through Florisil Standard extracied from U/va, then passed through Florisil

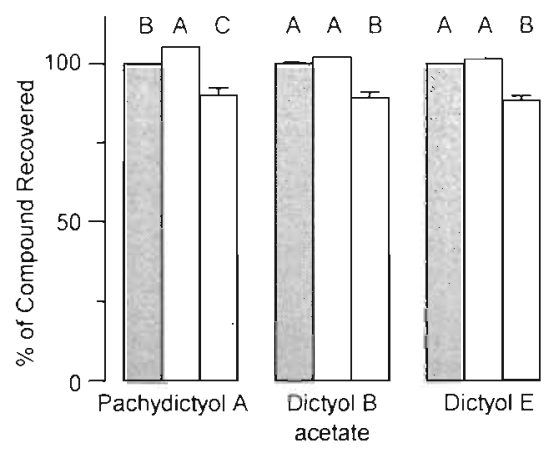

Fig. 3. Effectiveness of 2:1 DCM: $\mathrm{MeOH}$ at extracting freezedried Ulva sp. coated with dictyol $\mathrm{E}$, dictyol $\mathrm{B}$ acetate, and pachydictyol $A$, each at $0.2 \%$ dry mass. The left bar in each group represents the standard compounds injected directly into the HPLC and all data for each compound are normalized to this value. The middle bar in each group represents compounds that were prepared for injection as if they were a Dictyota spp. extract (i.e. passed through a Florisil column prior to HPLC injection). The right hand bar represents the yield of the compounds extracted from freeze-dried Ulva sp. $\mathrm{N}=10$ for each treatment and error bars show $+1 \mathrm{SE}$. For each compound, bars with the same letter above them do not differ significantly $(\alpha<0.05,1$-way ANOVA followed by Tukey's Studentized range test\}

were reduced by 42 to $73 \%$ when samples of $D$. ciliolata were stored for 25 to 27 wk (Fig. 4C). Placing tissues or extracts in solvents significantly reduced loss of dictyodial compared to freezing tissues without solvents. In $D$. menstrualis, the concentration of dictyodial in tissue or extracts stored in solvent did not differ from samples that were analyzed within 2 wk of collection, although dictyodial did decrease when tissue that was simply frozen for 13 and 25 to $27 \mathrm{wk}$ (Fig. 4C). Primary metabolites were also protected when algal tissue was submerged in solvent. Sterol yields were 11 to $15 \%$ (D. ciliolata) and 20 to $26 \%$ (D. menstrualis) lower in tissue samples frozen without solvent than in samples submerged in solvents (Fig. 4D)

\section{DISCUSSION}

When extracting nonpolar metabolites from wet or dried Dictyota ciliolata and $D$. menstrualis tissue, a double extraction in a 2:1 mixture of DCM:MeOH worked as well as or significantly better than DCM, $\mathrm{MeOH}$ or EtOH alone (Fig. 2). This solvent mixture should work well with a wide variety of lipophilic secondary metabolites because it contains a low-polarity solvent (DCM) and a high-polarity, water-miscible 

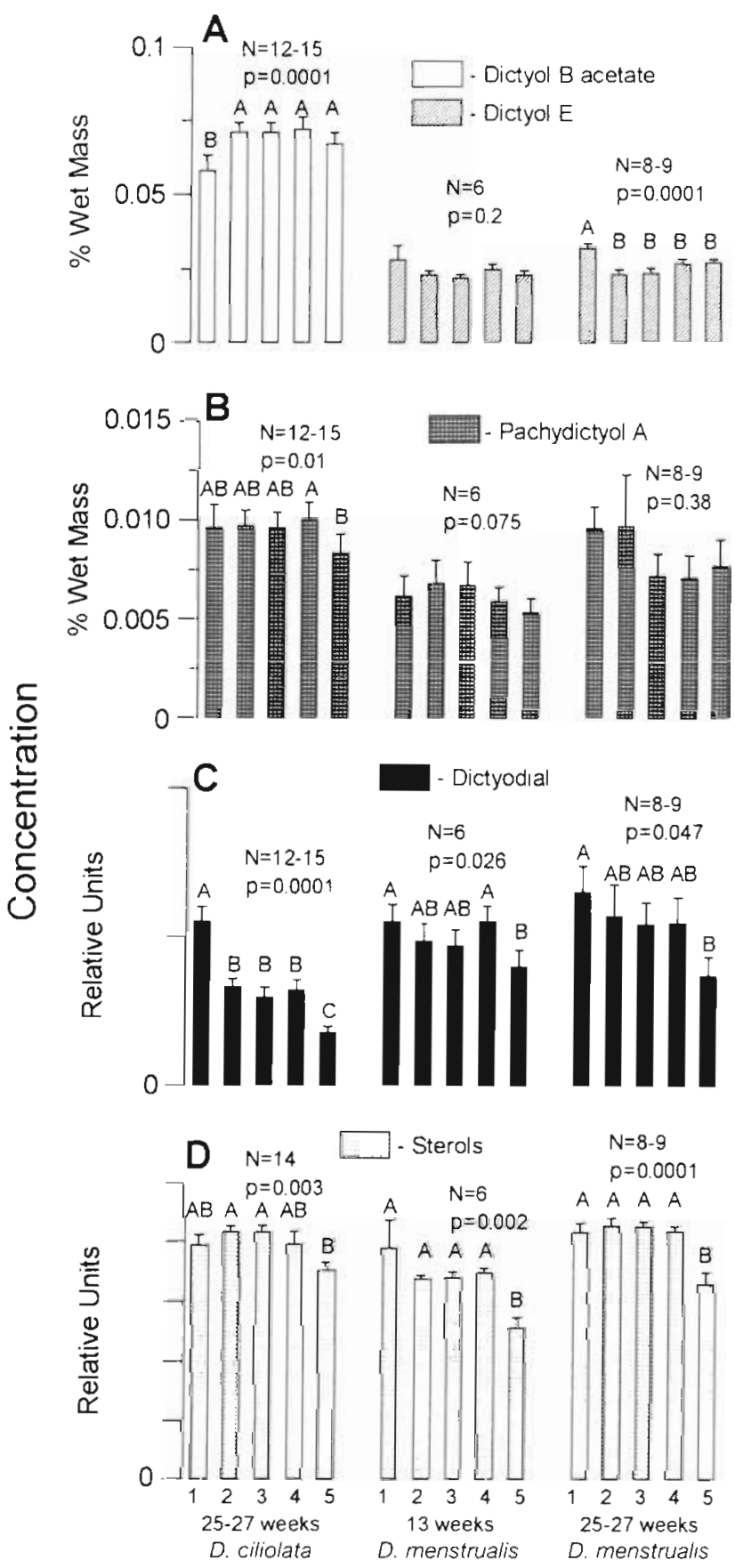

Fig. 4. Concentration of dictyols and sterols from Dictyota ciliolata stored for 25 to $27 \mathrm{wk}$ (left third of graphs) and D. menstrualis stored for $13 \mathrm{wk}$ (middle third) or 25 to $27 \mathrm{wk}$ (right third) in various ways at $-25^{\circ} \mathrm{C}$. The 5 storage treatments are, from left to right, (1) HPLC analysis within 2 wk of extraction, (2) the extract dissolved in DCM under nitrogen gas, (3) the extract dissolved in DCM under air, (4) wet tissue submerged in 2:1 DCM:MeOH, and (5) wet tissue frozen fresh. (A) Means +1 SE for dictyol B acetate in $D$. ciliolata and dictyol $E$ in D. menstrualis. (B, $C$, and D) Results for pachydictyol A, dictyodial, and sterols, respectively, in both $D$. ciliolata and $D$. menstrualis. For each third of each graph, bars with the same letter above them do not differ significantly $(\alpha<0.05$. Tukey's Studentized range test) solvent $(\mathrm{MeOH})$ that can penetrate cell membranes and extract a wide variety of lipids that differ in polarity. The 88 to $90 \%$ recovery of dictyols from freezedried Ulva sp. using 2:1 DCM:MeOH (Fig. 3) is similar to recoveries of vitamin $\mathrm{E}$ and $\beta$-carotene $(87 \%$ and $84 \%$, respectively; Aucoin et al. 1990), o-nitrophenol and methyl salicylate (about 95\%; Diehl et al. 1991), and $(+)$-cis, trans- $\left[{ }^{3} \mathrm{H}\right]$-abscisic acid (>90\%; Holappa \& Blum 1991) reported from similar terrestrial studies. However, we are uncertain that extraction of dictyoltreated Ulva sp. can be used to confidently conclude that we are obtaining similar percentage yields when we extract $D$. ciliolata and $D$. menstrualis.

Lyophilization dries samples without elevating temperature and is thus commonly used in hopes of avoiding loss or conversion of sensitive compounds. However, the extreme vacuum significantly reduced the amount of dictyodial in plant tissues that were freeze-dried (Fig. 2D). Thus freeze-drying should be used with caution because it can decrease the yield of unstable or volatile compounds (Hay et al. 1988b). Although lyophilization worked well for quantifying pachydictyol $A$ and dictyol $B$ acetate, separating lipophilic compounds from water using a DCM-water partition worked significantly better for dictyodial.

Whenever possible, samples should be extracted and analyzed soon after collection because compounds can decompose even if samples are frozen under nitrogen gas (e.g. dictyodial; Fig. 4C). Due to the remoteness of some field sites and to common constraints on time, it is often necessary to store samples for analysis at a future date. Analysis of a few representative samples should be made soon after collection so gross qualitative changes, and maybe even quantitative changes, in chemical composition can be detected. When immediate analysis is impossible, samples should be stored in a manner that minimizes changes in metabolite composition. We found that submersion in solvents before freezing afforded some protection against loss of pachydictyol A, dictyodial, and sterols in Dictyota ciliolata and of sterols and dictyodial in D. menstrualis (Fig. 4). There were no differences between storing samples as whole tissue submersed in 2:1 DCM:MeOH or as extracts dissolved in DCM

Although submersion in solvents protected some Dictyota ciliolata and D. menstrualis compounds from decompasition (Fig. 4), some solvents, alcohols in particular, can react with secondary metabolites to create chemical artifacts (Table 1). For example, in a few samples $(<5 \%)$ and in 1 mass extraction, dictyodial reacted with methanol to form a methoxy-bisacetal (Fig. 1). We do not know what initiated this reaction, but we were able to isolate this artifact and detect it using our HPLC methodology.

The explanation for the observed increase in the 
Table 1. Chemical processes that can decompose secondary metabolites or alter their structure during storage, extraction, and purification. The ordering of chemical processes in this table does not indicate their likelihood of occurrence with any particular secondary metabolite

\begin{tabular}{|ll|}
\hline Type of chemical process & Source \\
\hline Acid-catalyzed rearrangements & Stallard \& Faulkner (1974) \\
Air oxidation & Andersen \& Stonard (1979), Gerwick \& Fenical (1981), Oltz et al. (1988), \\
& Wiseman et al. (1990), Hedin et al. (1991), Peng \& Jay-Allemand (1991) \\
Apparent enzymatic conversions & Duffey \& Felton (1989), Paul \& Van Alstyne (1992), Teeyapant \& Proksch (1993) \\
Dimerization/polymerization & Fahy \& Andersen (1987), Bernart et al. (1992) \\
Photochemical reactions & \\
Isomerization & Guella et al. (1988) \\
Oxidation & Andersen \& Stonard (1979), Cork \& Krockenberger (1991) \\
Reactions of alcohols or water with the following functional groups commonly found in marine natural products \\
Aldehydes & This paper, Lindquist et al. (1988) \\
Carbon-carbon double bonds & Sun \& Fenical (1979), Carte \& Faulkner (1983), Boros et al. (1990) \\
Esters & Lindroth \& Pajutee (1987) \\
Epoxides & Van Altena (1988) \\
Furans & Walker \& Faulkner (1981) \\
Halogens & Anthoni et al. (1987) \\
Quinones & Urban \& Capon (1992) \\
Sulfates & Weinstein et al. (1975) \\
Thermal decomposition & Jones \& Sutherland (1968), Weinheimer et al. (1970), Cork \& Krockengerger (1991) \\
\hline
\end{tabular}

yield of dictyol $B$ acetate after samples were stored for 25 to $27 \mathrm{wk}$ is not apparent (Fig. 4A). Because the increase did not occur in other compounds which were quantified from the same HPLC sample as dictyol B acetate, inadvertent evaporation of solvent from the samples prior to injection into the HPLC is unlikely. The increase in dictyol $B$ acetate yield could have occurred if (1) dictyol B acetate was produced in the samples during storage or (2) a compound-specific change in supplies, standards, or equipment occurred during the 25 to $27 \mathrm{wk}$ samples were stored. The same problem exists for compounds that decreased by similar amounts among the samples stored for 13 to 27 wk (e.g. dictyol E stored for 25 to 27 wk, Fig. 4A). Because these results were necessarily confounded by having samples analyzed at different times, we cannot distinguish which explanation is responsible for the increase in dictyol $\mathrm{B}$ acetate or the decrease in dictyol $\mathrm{E}$. The significant 42 to $73 \%$ reduction in dictyodial in Dictyota ciliolata tissue stored for 25 to $27 \mathrm{wk}$ was most likely due to decomposition and not to instrument fluctuation or changes in supplies because the magnitude of the reduction was large; and, had a systematic change led to this reduction in dictyodial concentration, it also would have been apparent in $D$. menstrualis (Fig. 4C).

The bioactive nature of many secondary metabolites may arise from the presence of highly reactive functional groups. Secondary metabolites may deter consumers or competitors because they react with and disrupt the functions of physiologically important molecules such as enzymes or DNA. Because of this reactivity, these compounds also may undergo reactions that lead to their decomposition or conversion. Compound decomposition and conversion can be problematic because (1) they decrease yields of naturally occurring metabolites, (2) they mislead quantitative data, (3) they diminish the magnitude of metabolite activities in bioassays, and (4) bioactive properties of artifacts can be mistakenly attributed to naturally occurring metabolites. Table 1 lists several chemical processes that can lead to the decomposition or conversion of natural secondary metabolites. Because natural products chemists have the expertise to recognize chemical artifacts, collaborative efforts between ecologists and chemists can enhance the quality of projects examining ecological roles of secondary metabolites.

Because of the idiosyncrasies of different biological and chemical systems, the most efficient means of storing and extracting Dictyota ciliolata and $D$. menstrualis secondary metabolites cannot be applied to all quantitative studies of secondary metabolites. We found commonly used procedures like freeze-drying and preserving samples by freezing them had detrimental effects on algal chemical composition that were species- and compound-specific. However, based on the results of our investigation, we suggest that: (1) Among the storage methods we tested, simply freezing algal tissue was the least effective means of preserving both primary and secondary metabolites. Addition of organic solvents prior to freezing significantly increased yield of metabolites (Fig. 4). (2) Using a mixture of a nonpolar (e.g. DCM) and a polar (e.g. $\mathrm{MeOH}$ ) 
solvent for small-scale extraction of lipophilic compounds in replicate samples for HPLC quantification often produced greater yields, and never diminished yields, relative to using either type of solvent alone. (3) Highly reactive compounds are unlikely to be rigorously quantified unless factors contributing to their decomposition or conversion are identified and controlled [e.g. dictyodial's reaction with methanol (Fig. 1) or its loss when placed under high vacuum (Fig. 2D)].

For ecologists studying chemically mediated interactions among marine organisms, information on the variation of secondary metabolite composition within and among individuals and populations will be crucial for determining factors affecting the production of secondary metabolites and how ecologically important compounds may function to structure communities. This variance in metabolite concentration will most often be determined by analyzing multiple samples with chromatography methods. Our results show that methods of storing and extracting samples can significantly affect yields of biologically and ecologically important compounds (Figs. 2 \& 4). Thus, careful optimization of these methods is required to ensure quality data, surprisingly, sometimes even for the same compound in different species (Fig. 4C).

Acknowledgements. We are grateful to Julie Cronin for entering data from reams of chromatograms. We thank Joe Pawlik and 2 anonymous reviewers for criticisms and helpful comments that greatly improved this manuscript. This study was funded by NSF grants OCE 89-11872 and 92-02847 (M.E.H.) and OCE 89-15304 (N.L.).

\section{LITERATURE CITED}

Andersen, R. J., Stonard, R. J. (1979). Clionamide, a major metabolite of the sponge Cliona celata Grant. Can. J. Chem. 57: 2325

Anthoni, U., Chevolot, L., Larsen, C., Nielsen, P. H., Christophersen, C. (1987). Marine alkaloids. 12. Chartellines, halogenated beta-lactam alkaloids from the marine bryozoan Chartella papyracea. J. org. Chem. 52: 4709

Aucoin, R. R., Fields, P., Lewis, M. A., Philogene, B. J R., Arnason, J. T. (1990). The protective effect of antioxidants to a phototoxin-sensitive insect herbivore, Manduca sexta. J. chem. Ecol. 16: 2913-2924

Bernart, M. W., Gerwick, W. H., Coccoran, E. E., Lee, A. Y., Clardy, J. (1992). Laurencione, a heterocycle from the red alga Laurencia spectabilis. Phytochem. 31: 1273-1276

Boros, C. A., Stermitz, F. R., Harris, G. H. (1990). Iridoid glycosides and a new pyridine monoterpene alkaloid from Orthocarpus. New artifactual iridoid dienals. J. nat. Prod. 53: 72

Carlson, D. J., Lubchenco, J., Sparrow, M. A., Trowbridge, C. D. (1989). Fine-scale variability of lanosol and its disulfate ester in the temperate red alga Neorhodomela larix. J. chem. Ecol. 15: 1321-1333

Carte, B., Faulkner, D. J. (1983). Defensive metabolites from three nembrothid nudibranchs. J. org. Chem. 48: 2314
Cork, S. J., Krockenberger, A. K. (1991). Methods and pitfalls of extracting condensed tannins and other phenolics from plants: insights from investigations on Eucalyptus leaves. J. chem. Ecol. 17: 123-134

de Scisciolo, B, Leopold, D. J., Walton, D. C. (1990). Seasonal pattern of juglone in soil beneath Juglas nigra (black walnut) and influence of $J$. nigra on understory vegetation. J. chem. Ecol. 16: 1111-1130

Diehl, P. A., Guerin, P., Vlimant, M., Steullet, P. (1991). Biosynthesis, production site, and emission rates of aggregation-attachment pheromone in males of two Amblyomma ticks. J. chem. Ecol. 17: 833-847

Duffey, S. S., Felton, G. W. (1989). Plant enzymes in resistance to insects. In: Whitaker, J. R., Sonnet, D. E. (eds.) Biocatalysis in agricultural biotechnology. American Chemical Society, Washington, DC, p. 289-313

Fahy, E., Andersen, R. J. (1987). Minor metabolites of the marine hydroid Garveia annulata. Can. J. Chem. 65: 376

Faulkner, D. J. (1993). Marine natural products. Nat. Prod. Rep. 10: 497-539

Gerwick, W. H., Fenical, W. (1981). Ichthyotoxic and cytotoxic metabolites of the tropical brown alga Stypopodium zonale (Lamoroux) Papenfuss. J. org. Chem. 46: 22-27

Goodrich, B. S., Gambale, S., Pennycuik, P. R., Redhead, T. D. (1990). Volatiles from feces of wild male house mice: chemistry and effects on behavior and heart rate. J. chem. Ecol. 16: 2091-2106

Guella, G., Mancini, I., Zibrowius, H., Pietra, F. (1988) Novel aplysinopsin-type alkaloids from scleractinian corals of the family Dendrophylliidae of the Mediterranean and the Philippines. Configurational-assignment criteria, stereospecific synthesis, and photoisomerization. Helv. Chim. Acta 71:773

Hagerman, A. E. (1988). Extraction of tannin from fresh and preserved leaves. J. chem. Ecol. 14: 453-461

Hay, M. E., Duffy, J. E., Pfister, C. A., Fenical, W. (1987). Chemical defenses against different marine herbivores: Are amphipods insect equivalents? Ecology 68: 1567-1580

Hay, M. E., Paul, V. J., Lewis, S. M., Gustafson, K., Tucker, J., Trindell, R. N. (1988a). Can tropical seaweeds reduce herbivory by growing at night? Diel patterns of growth. nitrogen content, herbivory, and chemical versus morphological defenses. Oecologia 75: 233-245

Hay, M. E., Duffy, J. E., Fenical, W., Gustafson, K. (1988b) Chemical defense in the seaweed Dictyopteris delicatula: differential effects against reef fishes and amphipods. Mar. Ecol. Prog. Ser. 48: 185-192

Hay, M. E., Steinberg, P. D. (1992). The chemical ecology of plant-herbivore interactions in marine versus terrestrial communities. In: Rosenthal, G. A., Berenbaum, M. R. (eds.) Herbivores: their interactions with plant metabolites, Vol. II. Academic Press, Inc., New York, p. 371-413

Hedin, P. A., Parrott, W. L., Jenkins, J. N. (1991). Effects of cotton plant allelochemicals and nutrients on behavior and development of tobacco budworm. J. chem. Ecol. 17: 1107-1121

Holappa, L. D., Blum, U. (1991). Effects of exogenously applied ferulic acid, a potential allelopathic compound, on leaf growth, water utilization, and endogenous abscisic acid levels of tomato, cucumber, and bean. J chem. Ecol 17: $865-886$

Ilvessalo, H., Tuomi, J. (1989). Nutrient availability and accumulation of phenolic compounds in the brown alga Fucus vesiculosus. Mar. Biol. 101: 115-119

Johnson, C. R., Mann, K. H. (1986). The importance of plant defense abilities to the structure of seaweed communities: the kelp Laminaria longicruis de la Pylaie survives grazing 
by the snail Lacuna vincta (Montagu) at high population densities. J. exp. mar. Biol. Ecol. 97: 231-267

Jones, R. V. H., Sutherland, M. D. (1968). Terpenoid chemistry, Part XV, 1,5-dimethylcyclodeca-1,5,7-triene, the precursor of geijerene in Geijera parviflora. Aust. J Chem. 21: $2255-2264$

Kleiner, K. W. (1991). Stability of phenolic and protein measures in excised oak foliage. J. chem. Ecol, 17: 1243-1251

Lindquist, N., Fenical, W., Sesin, D. F., Ireland, C. M., Van Duyne, G. D., Forsyth, C. J., Clardy, J. (1988). Isolation and structure determination of the didemnenones, novel cytotoxic metabolites from tunicates. J. Am. Chem. Soc. 110: $1308-1309$

Lindroth, R. L., Pajutee, M. S. (1987). Chemical analysis of phenolic glycosides: art, facts, and artifacts. Oecologia 74: $144-148$

Muzika, R. M., Campbell, C. L., Hanover, J. W., Smith, A. L. (1990). Comparison of techniques for extracting volatile compounds from conifer needles. J. chem. Ecol. 16: 2713-2722

Newman, R. M., Hanscom, Z., Kerfoot, C. (1992). The watercress glucosinolate-myrosinase system: a feeding deterrent to caddisflies, snails, and amphipods. Oecologia 92 $1-7$

Norris, J. N., Fenical, W. (1985). Natural products chemistry: uses in ecology and systematics. In: Littler, M. M., Littler, D. S. (eds.) Handbook of phycological methods. Ecological field methods: macroalgae. Cambridge Univ. Press, New York, p. 121-145

Oltz, E. M., Bruening, R. C., Smith, M. J, Kustin, K., Nakanishi, K. (1988). The tunichromes: a class of reducing blood pigments from sea squirts: isolation, structures and vanadium chemistry. J. Am. Chem. Soc. 110:6162

Paul, V. J. (1992). Ecological roles of marine natural products. Comstock Pub. Assoc., Ithaca

Paul, V. J., Fenical, W. (1987). Natural products chemistry and chemical defense in tropical marine algae of the phylum Chlorophyta. In: Scheuer, P. J. (ed.) Bioorganic marine chemistry. Springer-Verlag, Berlin, p. 1-29

Paul, V. J., Van Alstyne, K. L. (1988). Chemical defense and chemical variation in some tropical Pacific species of Halimeda (Halimedaceae; Chlorophyta). Coral Reefs 6: $263-269$

Paul, V. J., Van Alstyne, K. L. (1992). Activation of chemical defenses in the tropical green algae Halimeda spp. J. exp. mar. Biol. Ecol. 160: 191-203

Pawlik, J. R. (1993). Marine invertebrate chemical defenses Chem. Rev. 93: 1911-1922

Peng, S., Jay-Allemand, C. (1991). Use of antioxidants in extraction of tannins from walnut plants. J. chem. Ecol. 17 : $887-896$

Pfister, C. A. (1992). Costs of reproduction in an intertidal kelp: patterns of allocation and life history consequences. Ecology 73: 1586-1596

Phillips, D. W., Towers, G. H. N. (1982). Chemical ecology of red algal bromophenols. I. Temporal interpopulational, and within-thallus measurements of lanosol levels in Rhodomela larix (Turner) C. Agardh. J. exp. mar. Biol. Ecol. 58: 285-293

Ragan, M. A., Jensen, A. (1978). Quantitative studies of brown algal polyphenols. Il. Seasonal variation in polyphenol content of Ascophyllum nodosum (L.) Le Jol. and Fucus vesiculosus L. J. exp. mar. Biol. Ecol. 34: 245-258

SAS (1991) SAS user's guide: statistics. SAS Institute, Inc., Cary, NC

Stallard, M. O., Faulkner, D. J. (1974). Chemical constituents of the digestive gland of the seahare Aplysia californica. II. Chemical transformations. Comp. Biochem. Physiol. 49B: 37

Steinberg, P. D. (1984). Algal chemical defense against herbivores: allocation of phenolic compounds in the kelp Alaria marginata. Science 223: 405-407

Steinberg, P. D. (1989). Biogeographical variation in brown algal polyphenolics and other secondary metabolites: comparison between temperate Australasia and North America. Oecologia 78: 373-382

Sun, H., Fenical, W. (1979). Rhipocephalin and rhipocephenali toxic feeding deterrents from the tropical marine alga Rhipocephalus phoenix. Tetrahedron Lett. 8: $685-688$

Teeyapant, R., Proksch, P. (1993). Biotransformation of brominated compounds in the marine sponge Verongia aerophoba-evidence for an induced chemical defense? Naturwissenschaften 80: 369-370

Tugwell, S., Branch, G. M. (1989). Differential polyphenolic distribution among tissues in the kelps Ecklonia maxima, Laminaria pallida, and Macrocystis angustifolia in relation to plant defense theory. J. exp. mar. Biol. Ecol. 129: $219-230$

Urban, S., Capon, R. J. (1992). 5-epi-isospongiaquinone, a new sesquiterpene/quinone antibiotic from an Australian marine sponge, Spongia hispida. J. nat. Prod. 55: 1638

Van Alstyne, K. L. (1988). Herbivore grazing increases polyphenolic defenses in the intertidal brown alga Fucus distichus. Ecology 69: 655-663

Van Alstyne, K. L. (1989). Adventitious branching as a herbivore-induced defense in the intertidal brown alga Fucus disticus. Mar, Ecol. Prog. Ser. 56: 169-176

Van Altena, I. A. (1988). Terpenoids from the brown alga Cystophora moniliformis. Aust. J. Chem. 41:49

Walker, R. P., Faulkner, D. J. (1981). Diterpenes from the sponge Dysidea amblia. J. org. Chem. 46: 1098-1102

Weinheimer, A. J., Youngblood, W. W., Washecheck, P. H., Karnes, T. K. B., Ceireszko, L. S. (1970). Isolation of the elusive (-)-germacrene-A from the gorgonian Eunicia mammosa. Chemistry of coelenterates Part XVIII. Tetrahedron Lett. 497-500

Weinstein, B., Rold, T L., Harrell, C. E. Jr, Burns, M. W. III, Waaland, J. R. (1975). Reexamination of the bromophenolics of the red alga Rhodomela larix. Phytochemistry 14: $2667-2670$

Wiseman, B. R., Gueldner, R. C., Lynch, R. E., Severson, R. F. (1990). Biochemical activity of centipedegrass against fall armyworm larvae. J. chem. Ecol. 16: 2677-2690

Yates, J. L., Peckol, P. (1993). Effects of nutrient availability and herbivory on polyphenolics in the seaweed Fucus vesiculosus. Ecology 74: 1757-1766

Zobel, A. M., Brown, S. A. (1988). Determination of furanocoumarins on the leaf surface of Ruta graveolens with an improved extraction technique. J. nat. Prod. 51: 941-946

Manuscript first received: March 11, 1994

Revised version accepted: November 18, 1994
This article was presented by J. Pawlik, Wilmington,

N. Carolina, USA 